\title{
$\mathrm{PC}$ 합성보의 수평접합면 전단력 전달성능 평가 및 설계법 분석
}

\author{
문정호 ${ }^{1)} \cdot$ 오영훈 ${ }^{2) \star ~}$ \\ ${ }^{1)}$ 한남대학교 건축학부 ${ }^{2)}$ 건양대학교 건축학과
}

\section{Evaluation of Design Method and Shear Transfer Capacity on the Horizontal Interface of PC Composite Beams}

\author{
Jeong-Ho Moon ${ }^{1)}$ and Young-Hun $\mathrm{Oh}^{2) *}$ \\ ${ }^{1)}$ Division of Architecture, Hannam University, Daejeon 306-791, Korea \\ ${ }^{2)}$ Dept. of Architecture, Konyang University, Nonsan 320-711, Korea
}

\begin{abstract}
The purpose of this study is to evaluate the horizontal shear strength on the interface between PC and cast-in-place concrete for PC composite beams. Six specimens were tested to examine the structural performance of the horizontal interface with different surface condition and stirrup detailing. Except for SF-291B specimen failed in flexural compression, strengths and deformation capacities of five specimens were determined by horizontal shear failure. Horizontal shear strengths by composite horizontal shear or shear friction in current codes could be used to predict the horizontal shear capacity of the interface for specimens. Also detailing for stirrup by PCI design provision could be used to accomplish the composite action in the interface.
\end{abstract}

Keywords : composite PC beam, interface, horizontal shear, shear force transfer, shear friction

\section{1. 서 론}

건축공사 현장에서 $\mathrm{PC}$ 공법은 거푸집작업을 최소화하 면서 공기단축과 구체공사의 품질향상을 기대할 수 있는 방안 중의 하나로 간주되고 있다. 특히 지하주차장, 할인 매장, 물류센터와 경기장 등과 같이 동일한 모듈을 갖도 록 내부공간을 구성한 건축물은 $\mathrm{PC}$ 공법을 적용하게 될 경우 효율성과 경제성 측면에서 우수한 결과를 기대할 수 있다.

아울러 국내 $\mathrm{PC}$ 공법의 최근 동향은 현장타설 철근콘 크리트구조의 접합부와 유사한 구조성능을 부여할 수 있 도록 합성 $\mathrm{PC}$ 공법을 채택하고 있다. 합성 $\mathrm{PC}$ 공법은 기 둥, 보 또는 슬래브 등의 부재 일부분을 공장에서 $\mathrm{PC}$ 로 제작한 후, 현장에서는 부재의 나머지 부분을 덧침 콘크 리트로 타설하여 전체 단면을 하나로 일체화하는 방법이다. 이러한 합성 $\mathrm{PC}$ 공법은 $\mathrm{PC}$ 부재와 덧침 콘크리트 간의 수 평분리타설부에서 미끄러짐 파괴가 발생하지 않을 경우 합성단면을 형성하게 되고, 결과적으로 전체 단면이 일 체로 거동하는 구조성능을 보여주게 된다.

*Corresponding author E-mail : youngoh@konyang.ac.kr Received September 7, 2012, Revised November 21, 2012, Accepted December 3, 2012

(C) 2013 by Korea Concrete Institute
합성 $\mathrm{PC}$ 보 역시 $\mathrm{PC}$ 부재의 상부에 덧침 콘크리트를 타 설했을 때, 휨변형 상태에서 수평분리타설부의 미끄러짐 변형을 촉발하는 수평전단응력 보다 큰 수평전단내력을 확보해 주어야 한다. 그렇지 않을 경우 합성 $\mathrm{PC}$ 보는 수 평접합부에서 미끄러짐 파괴를 나타내면서 부재의 강도 와 파괴모드가 모두 영향을 받게 된다. 따라서 합성 $\mathrm{PC}$ 공법의 $\mathrm{PC}$ 부재와 덧침 콘크리트 사이에 형성된 수평분 리타설부는 충분한 수평전단력 전달성능을 확보할 수 있 도록 설계, 시공하는 것이 필요하다.

이 연구에서는 합성보의 수평접합면에 대한 수평전단 력 저항성능을 평가하기 위하여 6 개의 접합면 전단성능 실험체를 대상으로 접합면의 표면상태, 전단철근의 보강 양과 상세 등의 구조변수에 대한 수평전단강도를 평가하였다.

\section{2. 연구의 필요성}

장경간 바닥구조나 지하주차장 $\mathrm{PC}$ 구조에서 지붕층과 같이 활하중이 크게 작용하는 $\mathrm{PC}$ 합성보는 큰 값의 전단 력과 모멘트와 함께 모멘트 반곡점 구간의 수평접합면에 서 미끄러짐변형을 유발하는 수평전단응력도 커지게 된다. 특히 연속단으로 시공한 PC합성보에서는 모멘트 반곡점 의 길이에 비해 부모멘트의 변화율이 크게 나타나므로, 수평접합면의 전단응력도 큰 값을 갖는다. 이 경우 접합 
면의 거칠기, 전단보강근의 양과 상세 등의 영향을 고려 하여 수평접합면의 전단강도를 산정하는 설계법을 명확 하게 확립할 필요가 있다.

합성구조에 사용되는 $\mathrm{PC}$ 부재는 공장의 생산에서 낮은 물시멘트비를 갖는 고강도 콘크리트에 대한 진동다짐의 영향으로 타설완료된 콘크리트 표면에는 블리딩과 레이

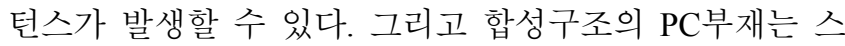
터럽과 같은 횡방향철근이 모두 배근된 상태에서 콘크리 트를 타설하기 때문에, 덧침 콘크리트 부분에 배근될 횡 철근의 정착단은 콘크리트가 묻은 상태로 생산될 수 있 다. 따라서 레이턴스가 존재하는 $\mathrm{PC}$ 부재의 표면상태, 또 는 콘크리트가 묻은 횡철근 정착단으로 구성된 합성 $\mathrm{PC}$ 구조의 수평접합면에 대하여 접합면 전단성능의 저하 가 능성을 고민하지 않을 수 없다.

현행 설계기준에서는 전단마찰설계법으로 접합면을 설계할 경우 $\mathrm{KCI}^{1)}$ 및 $\mathrm{ACl}^{2}$ 의 마찰계수 $(\mu)$ 와 $\mathrm{PCI}^{3}$ 의 유 효마찰계수 $\left(\mu_{e}\right)$ 를 규정하고 있지만, 구조설계 실무에서는 양자의 적용 방법에 대하여 명확하게 인식하지 못하는 것으로 파악되고 있다. 아울러 설계기준에서는 수평접합 면의 설계를 위하여 수평전단력 전달과 전단마찰로 구분 하여 제시하고 있지만, 실제 합성 $\mathrm{PC}$ 구조의 설계에 적용 하기 위해서는 명확한 설계지침이 필요한 상황이다. 아 울러 $\mathrm{PC}$ 공장에서는 $\mathrm{PC}$ 부재의 표면을 거칠게 만들기 위 하여 콘크리트 타설 후 쇠갈퀴 등으로 표면에 요철을 만 들고 있는데, 이러한 생산방식에 적합한 마찰계수와 구 조성능을 평가하는 것이 필요하다. 이에 이러한 문제점 을 해결하기 위하여 구조실험을 수행하고 합성보의 수평 접합부 전단성능을 평가하였다.

\section{3. 수평접합면의 전단설계 방법}

합성 $\mathrm{PC}$ 보의 수평접합면에 대한 전단강도의 산정은 합성보의 수평전단력 전달(horizontal shear transfer) 메커 니즘과 접합면 전단력 전달(interface shear transfer) 메커 니즘으로 구분할 수 있다. 접합면 전단력 전달 메커니즘 은 골재 맞물림작용 또는 전단마찰 등으로 불리어지고 있으며, 설계기준에서는 전단마찰로 표현하고 있다. Table 1 에서는 현행 설계기준에서 합성보의 수평전단강도와 전

Table 1 Design method for interface shear

\begin{tabular}{|c|c|c|}
\hline Code & Horizontal shear transfer & Shear-friction \\
\hline $\mathrm{KCI}^{1)}$ & $\begin{array}{l}\text { 17. Composite concrete } \\
\text { members } \\
\begin{array}{l}\text { 17.3.2 Horizontal shear } \\
\text { strength }\end{array}\end{array}$ & $\begin{array}{l}\text { 7.7 Shear-friction } \\
\text { 7.7.2 Shear-friction design } \\
\text { method }\end{array}$ \\
\hline $\mathrm{ACI}^{2)}$ & $\begin{array}{l}\text { 17. Composite concrete } \\
\text { flexural members } \\
\text { 17.5 Horizontal shear } \\
\text { strength }\end{array}$ & $\begin{array}{l}\text { 11.7 Shear-friction } \\
\text { 11.7.4 Shear-friction } \\
\text { design method }\end{array}$ \\
\hline $\mathrm{PCI}^{3)}$ & $\begin{array}{l}\text { 4.3.5 Horizontal shear } \\
\text { transfer in composite } \\
\text { members }\end{array}$ & 4.3.6 Shear-friction \\
\hline
\end{tabular}

단마찰 설계법으로 구분하여 접합면의 수평전단강도를 산정하는 규정을 비교하여 보여주고 있다.

합성 $\mathrm{PC}$ 보의 접합면에 작용하는 수평전단응력은 Fig. 1 에 나타난 바와 같이 모멘트 변곡점과 최대모멘트 발생 지점까지의 길이 $\left(l_{v h}\right)$ 에서 모멘트 차이로 인하여 발생하 는 전단흐름에 의해서 나타나는 전단응력이다.

합성 $\mathrm{PC}$ 보의 접합면에 작용하는 수평전단응력은 수직 전단응력을 사용하거나 또는 Fig. 2에 나타난 바와 같이 압축력이나 인장력의 실제 변화량 $\left(F_{h}\right)$ 을 고려하여 식 (1) 과 같이 산정한다.

$$
v_{u}=f_{h}=\frac{F_{h}}{A_{c r}}=\frac{F_{h}}{b_{v} l_{v h}}
$$

여기서, $\quad F_{h}=\left[0.85 f_{c c}^{\prime} A_{t o p}, A_{s} f_{y}+A_{p s} f_{p s}\right]_{\min }$ $A_{c r}=$ 수평접합면의 면적 $\left(=b_{v} l_{v h}\right)$

$l_{v h}=$ 최대모멘트와 모멘트변곡점까지의 길이 $b_{v}=$ 수평전단력이 작용하는 접합면의 폭

$\mathrm{ACI}^{2)}$ (콘크리트구조설계기준과과 동일) 및 $\mathrm{PCI}^{3)}$ 기준 에서의 접합면 전단강도 기준식은 접합면의 구조상세에 따라 3 가지의 경우로 구분하고 있으며, 이 논문에서는 3 가지를 각각 Case-I, Case-II 및 Case-III로 나타내었다.

- Case-I(ACI 17.5.3.1 \& 17.5.3.2, PCI 4.3.5, KCI 17.3.2) 은 조건 (1) 혹은 조건 (2) 중 하나를 만족하는 경우에 대하여 수평전단력 전달 메커니즘에 따라 접합면 전단 강도를 식 (2)에 의해 산정한다.
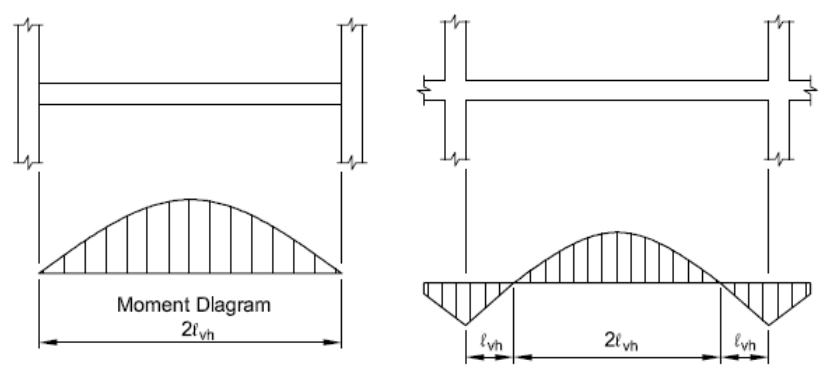

Fig. 1 Length $\left(l_{v h}\right)$ for horizontal shear

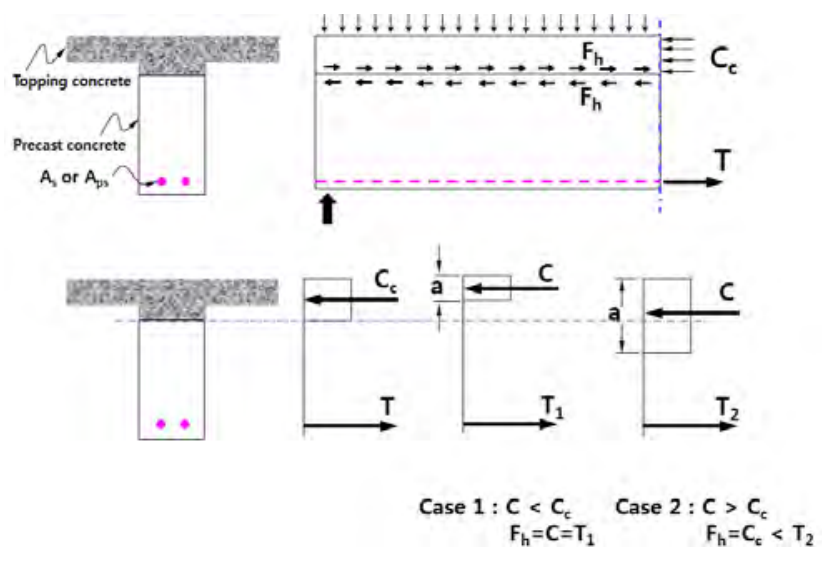

Fig. 2 Horizontal shear of simple composit PC beam 
조건 (1) : 수평전단보강근이 없고 접합면을 의도적 으로 거칠게 처리 $(6 \mathrm{~mm}$ 요철 $)$ 하는 경우

조건 (2) : 식 (3)에 의한 최소 전단보강근이 있고, 접 합면을 의도적으로 거칠게 하지 않는 경우

$v_{u} \leq \phi 0.56$

$A_{v, \min }=\frac{0.062 \sqrt{f_{c k}} b_{w} s}{f_{y}} \geq \frac{0.35 b_{w} s}{f_{y}}$

여기서, $b_{w}=$ 보의 복부 폭

$s=$ 전단보강근의 간격

- Case-II (ACI 17.5.3.3, PCI 4.3.5, KCI 17.3.2)는 다음의 조건 (1)과 조건 (2)를 모두 만족하는 경우로써 수평전 단력 전달 메커니즘에 따라 식 (4)를 적용한다.

조건 (1) : 최소 수평전단보강근이 있고 접합면을 의도 적으로 거칠게 처리 $(6 \mathrm{~mm}$ 요철 $)$ 하는 경우

조건 (2) : $v_{u} \leq \phi 3.5$

$v_{n h}=\left(1.8+0.6 \rho_{v} f_{y}\right) \lambda \leq 3.5$

여기서, $\rho_{v}=$ 전단철근비 $\left(=\frac{A_{v}}{b_{v} s}\right)$

$\lambda=$ 콘크리트의 단위중량과 연관된 수정계수

- Case-III (ACI 11.7.4, PCI 4.3.6, KCI 7.7.2)은 다음의 조 건 (1)을 만족하는 경우로써 전단마찰설계법에 따라 식 (5) 를 적용한다.

조건 (1) : $v_{u}>\phi 3.5$

$v_{n}=\mu \rho_{v} f_{y} \quad \leq\left(0.2 f_{c k}, 6.9\right)$

여기서, $\mathrm{ACI}$ 의 전단마찰설계에서는 마찰계수 $(\mu)$ 를 그대 로 사용하며, $\mathrm{PCI}$ 의 전단마찰설계법은 마찰계수 $(\mu)$ 대신 에 유효마찰계수 $\mu_{e}=\frac{6.9 \lambda^{2} \mu}{v_{u}} \leq \mu_{e(\max )}$ 를 사용한다. Table 2 는 $\mathrm{PCI}$ 기준에서 제시한 유효마찰계수 $\left(\mu_{e}\right)$ 의 최대값과 전단강도 상한값을 $\mathrm{ACI}$ 의 마찰계수 $(\mu)$ 와 연결지어 보여 주고 있다.

현행 설계기준에서는 이미 굳은 콘크리트에 새로운 콘 크리트를 타설하는 경우 레이턴스가 없도록 깨끗한 표면
Table 2 Coefficient for shear-friction design in $\mathrm{PCl}$

\begin{tabular}{l|c|c|l}
\hline Interface condition & $\mu$ & $\mu_{e(\max )}$ & Maximum $V_{u}=\phi V_{n h}$ \\
\hline \hline $\begin{array}{l}\text { Concrete to concrete, } \\
\text { cast monolithically }\end{array}$ & $1.4 \lambda$ & 3.4 & $0.30 \lambda^{2} f_{c k} A_{c r} \leq 6.9 \lambda^{2} A_{c r}$ \\
\hline $\begin{array}{l}\text { Concrete to concrete } \\
\text { with roughened surface }\end{array}$ & $1.0 \lambda$ & 2.9 & $0.25 \lambda^{2} f_{c k} A_{c r} \leq 6.9 \lambda^{2} A_{c r}$ \\
\hline Concrete to concrete & $0.6 \lambda$ & 2.2 & $0.20 \lambda^{2} f_{c k} A_{c r} \leq 5.6 \lambda^{2} A_{c r}$ \\
\hline Concrete to steel & $0.7 \lambda$ & 2.4 & $0.20 \lambda^{2} f_{c k} A_{c r} \leq 5.6 \lambda^{2} A_{c r}$ \\
\hline
\end{tabular}

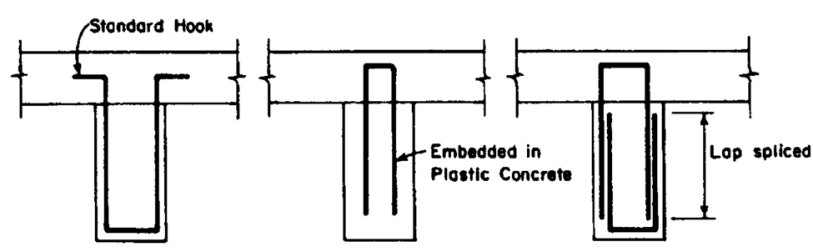

Fig. 3 Ties for horizontal shear ${ }^{4}$

상태를 요구하고 있다. 또한 수평전단철근은 전단력의 분포를 반영하여 접합면에 배치하는 간격을 결정하고, 철근의 양쪽은 정착길이를 확보하도록 갈고리 또는 특수 한 장치에 용접하여 항복강도를 발휘하도록 정착하는 것 을 요구하고 있다. 따라서 $\mathrm{PC}$ 부재의 생산과정에서 형성 된 접합면의 레이턴스 또는 수평전단철근의 갈고리부분 에 묻은 콘크리트 등은 접합면의 전단성능을 저하시키는 요소로 작용할 수 있다.

\section{4. 실험계획 및 방법}

이 연구에서는 연속지지된 합성 $\mathrm{PC}$ 보의 단부에서 부 모멘트에 의한 수평접합면의 전단성능에 영향을 미치는 구조변수의 특성을 평가하기 위하여 구조실험을 계획하 였다. 실험체의 변수는 접합면의 마감상태(현행 $6 \mathrm{~mm}$ 의 거칠기, 레이턴스 제거를 위한 지연제 도포, 전단키 설 치)와 $\mathrm{PC}$ 부재의 상부에 돌출되는 수평전단철근에 콘크리 트가 부착되는 것을 방지하기 위한 보양의 유·무, 그리고 수평전단철근의 양을 고려하였다. 접합면 전단성능 실험 체의 변수와 형상은 Table 3 및 Fig. 4에 나타나 있다. 모 든 실험체는 $400 \times 600 \mathrm{~mm}$ 의 직사각형 단면으로 구성되었

Table 3 Experimental variables for specimens

\begin{tabular}{|c|c|c|c|c|c|c|c|c|}
\hline \multirow{3}{*}{ Specimen } & \multicolumn{8}{|c|}{ Variables } \\
\hline & \multicolumn{4}{|c|}{ Horizontal shear reinforcement } & \multirow{2}{*}{$\begin{array}{l}\text { Shear } \\
\text { design }\end{array}$} & \multirow{2}{*}{$\begin{array}{l}\text { Interface } \\
\text { surface }\end{array}$} & \multirow{2}{*}{$\begin{array}{c}\text { Stirrup } \\
\text { plastic cover }\end{array}$} & \multirow{2}{*}{ Shear key } \\
\hline & Ties & $\rho_{v}$ & $f_{v y}(\mathrm{MPa})$ & $\rho_{v v} f_{v y}(\mathrm{psi})$ & & & & \\
\hline SF-1027 & D16@120 (double) & 0.0171 & 430 & 1027 & \multirow{3}{*}{ Case-III } & Normal & Yes & - \\
\hline SF-685A & \multirow{2}{*}{ D16@180 (double) } & \multirow{2}{*}{0.0114} & \multirow{2}{*}{430} & \multirow{2}{*}{685} & & Normal & Yes & - \\
\hline SF-685B & & & & & & Normal & No & - \\
\hline SF-291A & \multirow{3}{*}{ D13@200 (double) } & \multirow{3}{*}{0.0048} & \multirow{3}{*}{430} & \multirow{3}{*}{291} & \multirow{3}{*}{ Case-II } & Normal & Yes & - \\
\hline SF-291B & & & & & & w/o laitance & Yes & - \\
\hline SF-291C & & & & & & Normal & Yes & Yes \\
\hline
\end{tabular}


으며, $\mathrm{PC}$ 와 덧침 콘크리트의 설계기준 콘크리트압축강도 는 각각 $40 \mathrm{MPa}$ 와 $24 \mathrm{MPa}$ 로 계획하였다. 이때 덧침 콘크 리트의 두께는 $160 \mathrm{~mm}$ 로 계획하여, $\mathrm{PCI}$ 설계기준 ${ }^{3)}$ 의 수 평전단철근 정착조건을 만족하도록 하였다. 아울러 접합 면에 작용하는 수평전단력은 부모멘트 구간에서 발생하 는 인장력의 변화량 $\left(F_{h}=A_{s} f_{y}\right)$ 으로 결정된다.

Table 3에 나타난 실험체명칭 중 $1027,685,291$ 은 전 단철근비와 항복강도의 곱으로 나타낸 전단철근의 보강 양을 의미하며, 291시리즈는 합성보의 수평전단력 전달 메커니즘에 의한 전단성능을 평가하기 위한 것이다.

실험체의 전단철근 보강양이 동일한 경우 철단철근의 보양유무, 접합면의 레이턴스 제거를 위한 공정 추가 또 는 전단키의 설치에 따른 전단성능을 평가하기 위하여 실험변수를 구성하였다.

실험체는 Table 4에 나타난 바와 같이 휨강도 보다 큰 값의 전단강도를 갖도록 계획하여, 휨항복에 의해 1 차적 으로 내력이 지배되도록 하였다. 즉 합성 $\mathrm{PC}$ 단면은 휨항 복을 위한 인장력 $\left(A_{s} f_{y}\right)$ 이 접합면의 미끄러짐전단을 유발 하는 수평전단력 $\left(\mathrm{F}_{\mathrm{h}}\right)$ 으로 작용하게 된다. 이때 수평전단력
$\left(\mathrm{F}_{\mathrm{h}}\right)$ 은 마찰계수 또는 유효마찰계수를 사용한 전단마찰설 계법, 또는 수평전단력 전달메커니즘을 적용하여 산정한 접합면 전단강도와 비교, 평가하게 될 것이다.

한편 휨내력 계산을 위한 주근(재질 SD500의 D25)의 항복강도는 $520 \mathrm{MPa}$ 을, 수평전단근(제질 $\mathrm{SD} 400$ 의 철근) 의 항복강도는 $430 \mathrm{MPa}$ 을 사용하여 실제 항복강도와 가 까운 값을 실험체 설계과정에 적용하였다.

콘크리트의 압축강도를 확인하기 위한 공시체는 실험 체와 동일한 조건으로 양생하고 실험체의 실험일정에 맞 추어 강도시험을 실시함으로써 콘크리트의 압축강도를 확인하였으며, 그 결과를 Table 5에 나타내었다. 한편 실 험체에 사용한 철근은 KS D 3504에 의해 인장시험을 수 행하였으며, 그 결과는 Table 6에 나타내었다.

실험체는 지점길이 $2600 \mathrm{~mm}$ 의 단순보 중앙부를 중심 으로 좌우 각 $250 \mathrm{~mm}$ 의 위치에서 $\mathrm{P} / 2$ 의 하중이 가력되도 록 설치하였다. 실험체는 부모멘트를 받는 PC 합성보의 연속단을 대상으로 선정한 것이므로 덧침 콘크리트를 타 설한 부분에서 휨인장응력이 발생하도록 실험을 수행하 였다. 실험체는 가력점 하부에서 측정한 변위를 기준으
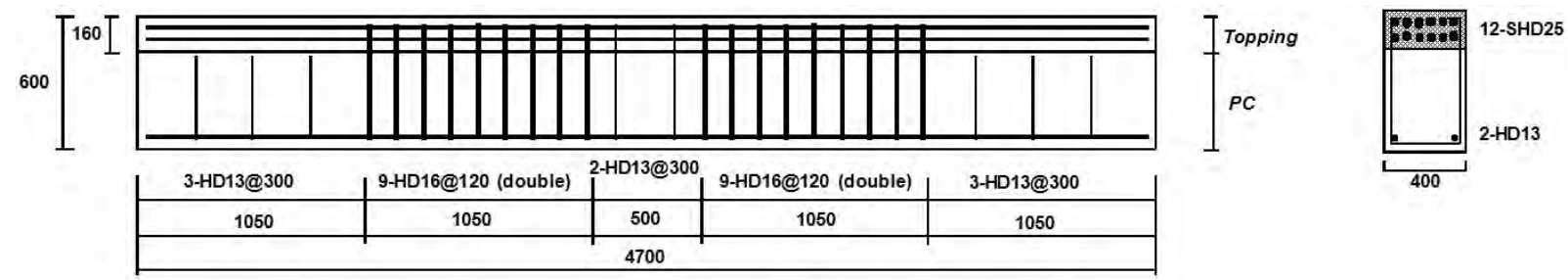

(a) SF-1027 specimen
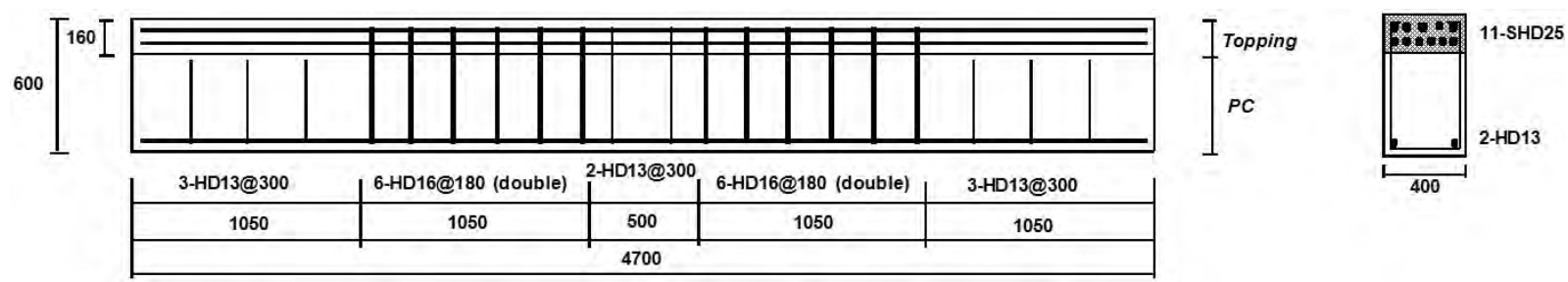

(b) SF-685A and SF-685B specimen
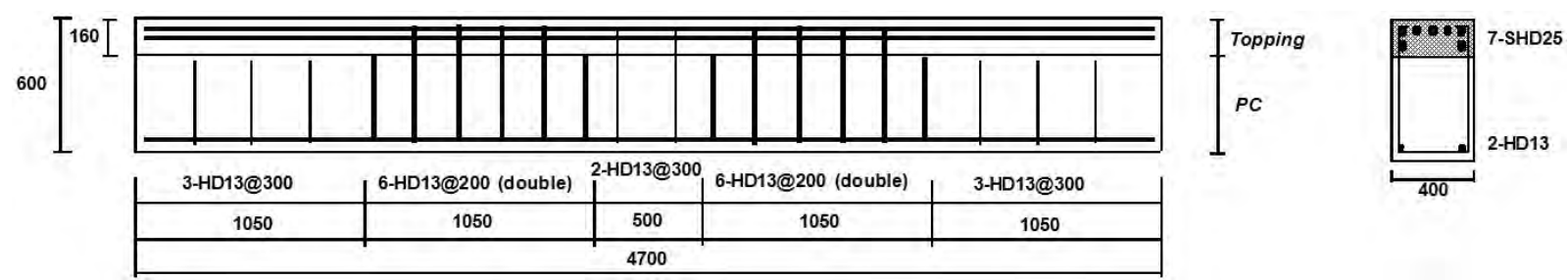

(c) SF-291A and SF-291B specimen
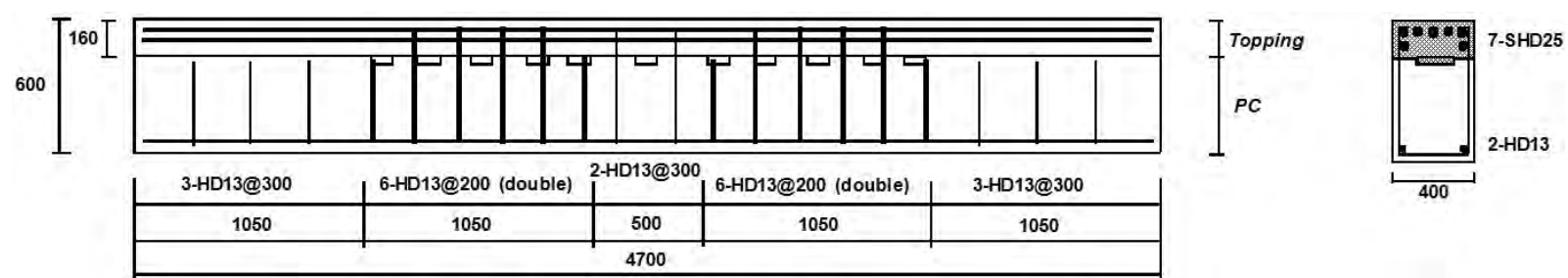

(d) SF-291C specimen

Fig. 4 Configuration and reinforcement for specimens 
Table 4 Design strength for specimens with roughened interface

\begin{tabular}{|c|c|c|c|c|c|c|c|c|c|c|c|c|c|c|c|}
\hline \multirow{2}{*}{ Specimen } & \multirow{2}{*}{$\begin{array}{c}\mathrm{d} \\
(\mathrm{mm})\end{array}$} & \multicolumn{2}{|c|}{$\begin{array}{c}f_{c k} \\
(\mathrm{MPa})\end{array}$} & \multicolumn{2}{|c|}{$\begin{array}{c}\text { Tensile } \\
\text { reinforcement }\end{array}$} & \multicolumn{2}{|c|}{$\begin{array}{c}\text { Shear } \\
\text { reinforcement }\end{array}$} & \multirow{2}{*}{$\mid \begin{array}{c}\text { Shear span, } \\
\text { a }(\mathrm{mm})\end{array}$} & \multicolumn{3}{|c|}{ Calculated strength } & \multicolumn{4}{|c|}{ Horizontal shear at the interface $(\mathrm{kN})$} \\
\hline & & $\mathrm{PC}$ & Topping & Rebar & $\begin{array}{c}f_{y} \\
(\mathrm{MPa}) \\
\end{array}$ & Rebar & $\begin{array}{c}f_{v y} \\
(\mathrm{MPa})\end{array}$ & & $\begin{array}{r}2 \mathrm{~V}_{\mathrm{n}} \\
(\mathrm{kN}) \\
\end{array}$ & $\begin{array}{c}2 \mathrm{M}_{\mathrm{n}} / \mathrm{a} \\
(\mathrm{kN})\end{array}$ & \begin{tabular}{|c}
$\begin{array}{c}\text { Failure } \\
\text { mode }\end{array}$ \\
\end{tabular} & $\begin{array}{c}\mathrm{F}_{\mathrm{h}} \\
\left(=A_{s} f_{y}\right)\end{array}$ & \begin{tabular}{|c|}
$\mathrm{V}_{\mathrm{nh}}^{(1)}$ \\
$(17.5 .3)$ \\
\end{tabular} & $\begin{array}{c}\mathrm{V}_{\mathrm{nh}}^{(2)} \\
\text { (ACI11.7.4) }\end{array}$ & $\begin{array}{c}\mathrm{V}_{\mathrm{nh}}{ }^{(3)} \\
\text { (PCI4.3.6) } \\
\end{array}$ \\
\hline SF-1027 & 520 & 40 & 24 & $\begin{array}{c}12-\mathrm{SH} \\
\mathrm{D} 25\end{array}$ & 520 & \begin{tabular}{|c|} 
D16@ \\
120 \\
(double) \\
\end{tabular} & 430 & 1050 & 3405 & 2433 & Flexure & 3164 & 1470 & $\begin{array}{c}2016 \\
(\mu=1.0)\end{array}$ & $\begin{array}{c}2520 \\
\left(\mu_{e}=1.0\right)\end{array}$ \\
\hline SF-685B & 520 & 40 & 24 & $\begin{array}{c}11-\mathrm{SH} \\
\mathrm{D} 25\end{array}$ & 520 & $\begin{array}{c}\text { D16@ } \\
180 \\
\text { (double) }\end{array}$ & 430 & 1050 & 2416 & 2283 & Flexure & 2900 & 1470 & $\begin{array}{c}2016 \\
(\mu=1.0)\end{array}$ & $\begin{array}{c}\mathbf{2 5 2 0} \\
\left(\mu_{e}=1.34\right)\end{array}$ \\
\hline $\begin{array}{l}\text { SF-291A } \\
\text { SF-291B } \\
\text { SF-291C }\end{array}$ & 540 & 40 & 24 & $\begin{array}{l}7-\mathrm{SH} \\
\mathrm{D} 25\end{array}$ & 520 & $\begin{array}{c}\text { D13@ } \\
200 \\
\text { (double) }\end{array}$ & 430 & 1050 & 1766 & 1660 & Flexure & 1845 & 1280 & $\begin{array}{c}\mathbf{8 7 4} \\
(\mu=1.0)\end{array}$ & $\begin{array}{c}1364 \\
\left(\mu_{e}=1.56\right)\end{array}$ \\
\hline
\end{tabular}

where, (1) $V_{n h}=\left(1.8+0.6 \rho_{v} f_{y}\right) \lambda b_{v} l_{v h} \leq 3.5 b_{v} l_{v h}$

(2) $V_{n h}=\mu A_{v} f_{y}$

(3) $V_{n h}=\mu_{e} A_{v} f_{y}$

Table 5 Compressive strength for concretes

\begin{tabular}{c|c|c}
\hline Specimen & PC $(\mathrm{MPa})$ & Topping concrete $(\mathrm{MPa})$ \\
\hline \hline SF-1027 & 48.5 & 34.5 \\
\hline SF-685A & 56.6 & 32.5 \\
\hline SF-685B & 56.6 & 32.5 \\
\hline SF-291A & 46.1 & 33.7 \\
\hline SF-291B & 44.3 & 57.9 \\
\hline SF-291C & 49.7 & 46.9 \\
\hline
\end{tabular}

Table 6 Tensile strength for reinforcements

\begin{tabular}{c|c|c|c|c|c}
\hline Rebar & Grade & $\begin{array}{c}f_{y} \\
(\mathrm{MPa})\end{array}$ & $\begin{array}{c}f_{u} \\
(\mathrm{MPa})\end{array}$ & $\begin{array}{c}\epsilon_{y} \\
\left(\times 10^{-6}\right)\end{array}$ & $\begin{array}{c}E_{s} \\
(\mathrm{MPa})\end{array}$ \\
\hline \hline $\mathrm{D} 13$ & \multirow{2}{*}{$\mathrm{SD} 400$} & 519 & 651 & 2794 & $1.86 \times 10^{5}$ \\
\cline { 3 - 6 } $\mathrm{D} 16$ & & 428 & 584 & 2257 & $1.90 \times 10^{5}$ \\
\hline $\mathrm{D} 25$ & \multirow{2}{*}{ SD500 } & 543 & 703 & 2377 & $2.27 \times 10^{5}$ \\
\hline
\end{tabular}
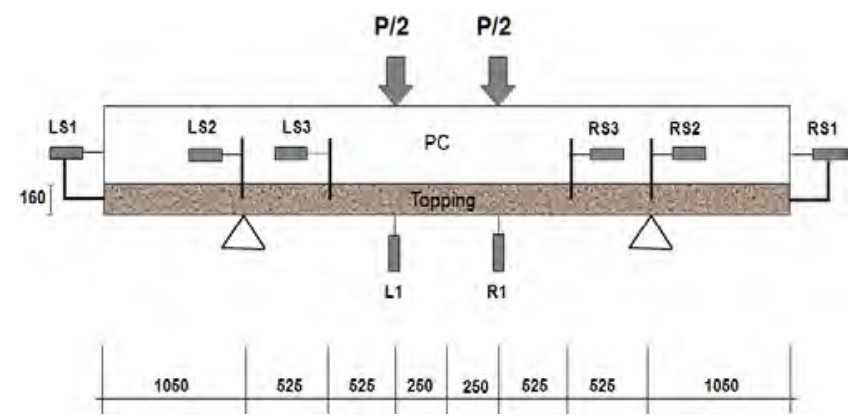

Fig. 5 Test set-up (unit: $\mathrm{mm}$ )

로 변위제어방식의 단조증가 하중을 가력하였다. 실험체 의 설치상황과 변위측정 위치는 Fig. 5에 나타나 있다.

\section{5. 실험 결과 및 분석}

\section{1 균열발생 및 파괴특성}

Fig. 6에서는 실험체의 최종파괴시 발생한 균열 양상을

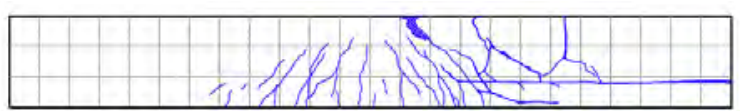

(a) SF-1027 specimen

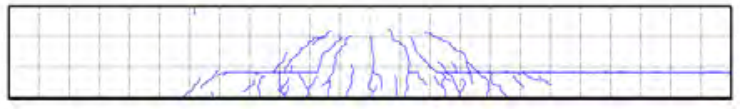

(b) SF-685A specimen

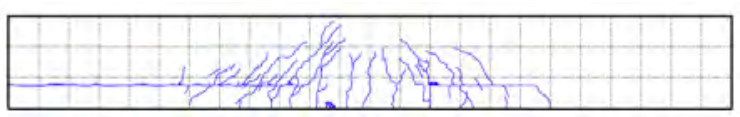

(c) SF-685B specimen

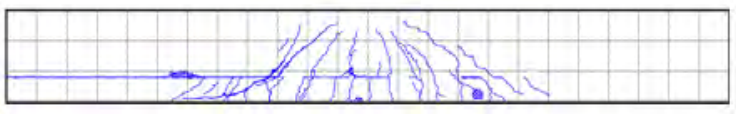

(d) SF-291A specimen

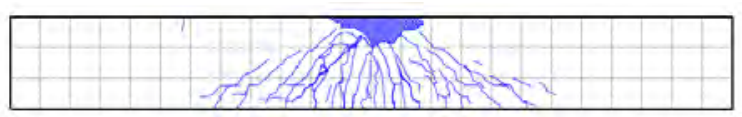

(e) SF-291B specimen

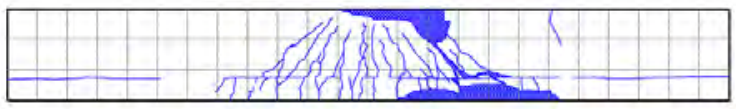

(f) SF-291C specimen

Fig. 6 Cracking pattern at failure

보여주고 있다. 콘크리트 설계기준압축강도를 사용하여 계산한 휨균열하중은 $182 \mathrm{kN}\left(M_{c r}=95.6 \mathrm{kNm}\right)$ 이며, 대부분 의 실험체는 약 $170 \mathrm{kN}$ 의 하중이 작용할 때 가력점 하부 인장면에서 초기 휨균열이 발생하였다.

SF-1027 실험체는 $588 \mathrm{kN}$ 의 하중에서 휨전단균열이 나 타났으며, $1770 \mathrm{kN}$ 의 최대하중에 도달하면서 우측 접합 면의 미끄러짐 현상과 PC 부재의 복부를 관통하는 사인 장 균열이 동시에 발생하면서 수평전단파괴를 보여주었다.

SF-685A 실험체는 $568 \mathrm{kN}$ 의 하중에서 휨전단균열이 
발생하였으며, $617 \mathrm{kN}$ 의 하중에서 좌, 우측 접합면을 따 라 수평균열이 발생한 후 $1912 \mathrm{kN}$ 의 최대하중에서는 우 측 접합면에서 미끄러짐에 의한 수평전단력으로 최종파 괴하였다.

$\mathrm{SF}-685 \mathrm{~B}$ 실험체는 $1000 \mathrm{kN}$ 의 하중이 작용할 때 좌, 우 측의 복부에서 사인장 균열과 접합면을 따라 형성된 수 평균열이 발생하였다. 이후 $1719 \mathrm{kN}$ 의 최대하중에 도달 하면서 좌측 접합면의 미끄러짐 현상과 $\mathrm{PC}$ 부재의 복부 를 관통하는 사인장 균열이 동시에 발생하면서 수평전단 파괴를 보여주었다.

SF-291A 실험체는 $578 \mathrm{kN}$ 의 하중에서 좌, 우측 접합면 을 따라 수평균열이 발생하였으며, $1744 \mathrm{kN}$ 의 최대하중 이 작용할 때 좌측 접합면의 미끄러짐 현상과 사인장 균 열이 동시에 발생하는 수평전단파괴를 보여주었다.

$\mathrm{SF}-291 \mathrm{~B}$ 실험체는 $1020 \mathrm{kN}$ 의 하중에서 좌, 우측 접합 면에서 미소한 길이로 수평균열이 발생하였다. 이후 $1867 \mathrm{kN}$ 의 최대하중에 도달하면서 중앙부의 인장측 휨균열이 크 게 벌어지면서 가력면 하부의 콘크리트가 압괴되는 휨압 축파괴를 보여주었다.

SF-291C 실험체는 $490 \mathrm{kN}$ 의 하중에서 우측 접합면을 따라 수평균열이 발생하였으며, $1584 \mathrm{kN}$ 의 최대하중에 도달하면서 우측 접합면의 미끄러짐과 사인장 균열이 함 께 나타나는 수평전단파괴를 보여주었다.

\section{2 하중-변위 관계}

Fig. 7에서는 Case-II와 Case-III로 구분한 실험체의 하 중-변위를 비교하여 보여주고 있다. SF-1027, SF-685A, $\mathrm{SF}-685 \mathrm{~B}$ 그리고 $\mathrm{SF}-291 \mathrm{~A}$ 실험체는 $6.6 \sim 8.4 \mathrm{~mm}$ 의 변위 상태에서 하중이 급격하게 저하하는 하중-변위 관계를 보여주고 있다. 이들 실험체가 보여준 최대하중은 Table 4 에 나타난 공칭휨강도 $\left(2 \mathrm{M}_{\mathrm{n}} / \mathrm{a}\right)$ 와 전단강도 $\left(2 \mathrm{~V}_{\mathrm{n}}\right)$ 보다 작 은 값으로서 휨내력 또는 전단내력에 도달하지 못하고 다른 원인에 의해 파괴가 발생한 것으로 판단할 수 있다. 이는 수평균열이 발생한 수평접합면을 따라 미끄러짐변 형이 나타나면서 합성단면이 분리되었기 때문에 단면의 휨강성이 급격히 감소하면서 하중저항능력이 상실하는데 서 기인한 것으로 판단된다.

반면 SF-291B 및 SF-291C 실험체는 최대내력에 도달 한 이후에도 하중-변위 관계에서 급격한 내력저하 현상 은 나타나지 않았다. 그러나 SF-291B 실험체의 경우에는 공칭휨강도 $\left(2 \mathrm{M}_{\mathrm{n}} / \mathrm{a}=1660 \mathrm{kN}\right)$ 보다 큰 $1867 \mathrm{kN}$ 의 최대하중 을 보여주고 있지만, SF-291C 실험체는 공칭휨강도 보다 작은 $1584 \mathrm{kN}$ 의 최대하중을 보여주고 있다. 이는 SF-291C 실험체의 경우에도 Fig. 6(c)에 나타난 바와같이 $\mathrm{PC}$ 부재 와 덧침 콘크리트의 접합면에서 수평전단균열이 발생하 면서 나타난 미끄러짐변형에 의해 휨강도까지 발현되지 못하고 내력이 제한된 것으로 판단된다.

결과적으로 SF-291B 실험체를 제외한 5 개의 실험체는 수평접합면의 미끄러짐변형에 의해 휨내력과 수직변형능
력이 모두 제한되는 취성적 구조성능을 갖는 것으로 평 가되었다.

\section{3 접합면 수평전단강도의 평가}

Fig. 8 에서는 2 가지 접합면 표면조건 $(6 \mathrm{~mm}$ 거칠기와

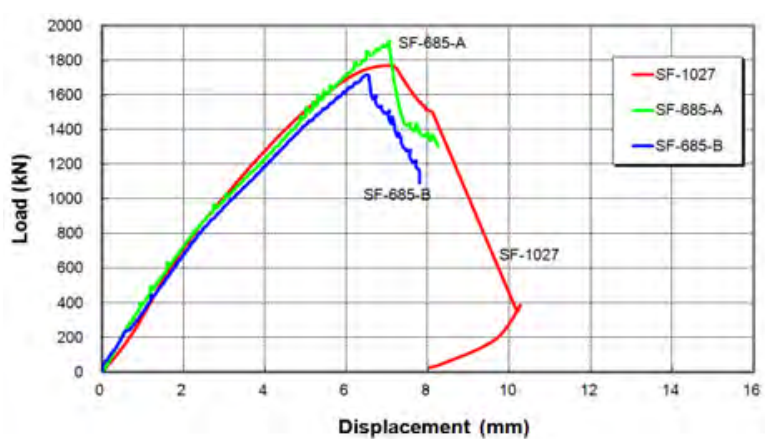

(a) Case-III shear design method

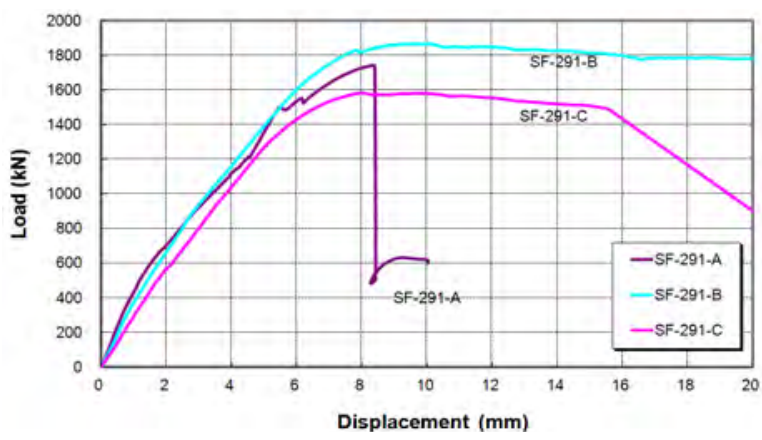

(b) Case-II shear design method

Fig. 7 Load vs. deflection curves

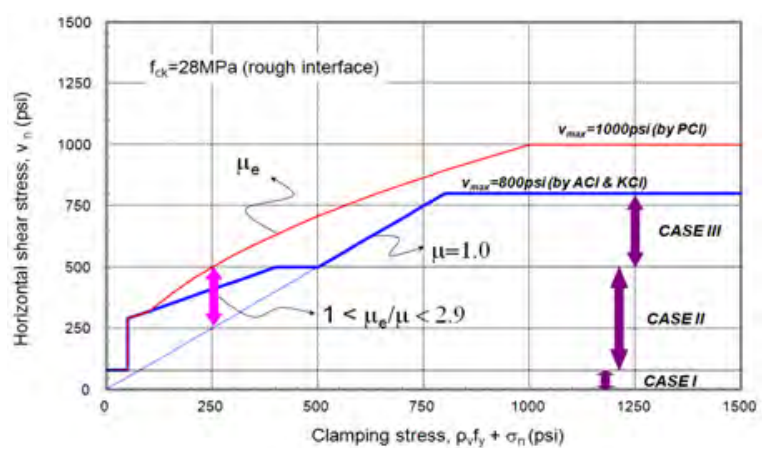

(a) Interface shear design for $\mu=1.0$

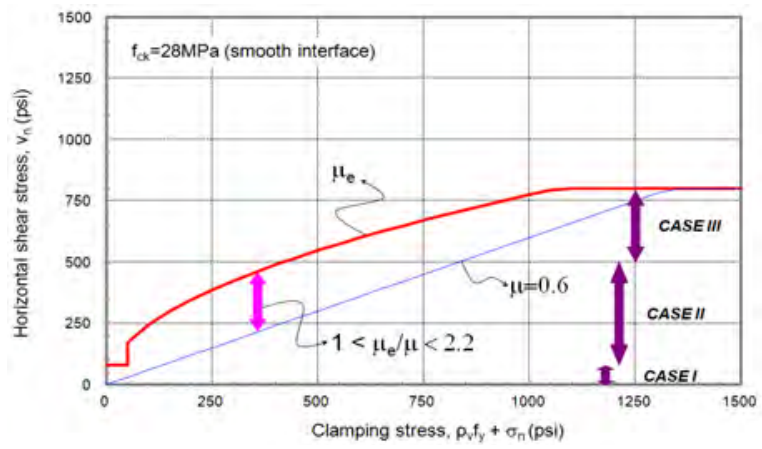

(b) Interface shear design for $\mu=0.6$

Fig. 8 Shear design with interface roughness 
매끈한 표면)에 따라 마찰계수를 각각 1.0 과 0.6 으로 적 용하여 산정한 $\mathrm{ACI}$ 와 $\mathrm{PCI}$ 의 전단마찰강도를 비교하여 보여주고 있다. 전단마찰설계법으로 구한 전단강도는 $\mathrm{PCI}$ 의 방식으로 산정한 경우에서 항상 크게 나타나고 있으 며, 이는 마찰계수보다 큰 값의 유효마찰계수를 적용하 기 때문에 나타나는 당연한 결과이다.

접합면 전단성능 실험체의 수평전단강도는 실험체의 최대하중으로부터 최대모멘트 $\left(\mathrm{M}_{\max }\right)$ 를 구함으로써 수평 전단력 $\left(\mathrm{F}_{\mathrm{h}}\right)$ 을 계산할 수 있고, 접합면의 전단강도 $\left(\mathrm{V}_{\mathrm{nh}}\right)$ 는 3장에서 설명한 Case-II 및 Case-III의 산정식을 사용하여 평가하였다. 이때 $\mathrm{PCI}$ 설계방법에 의한 유효마찰계수 $\left(\mu_{e}\right)$ 는 다음과 같이 계산하였다.

$$
\mu_{e}=\frac{6.9 \lambda^{2} A_{c r} \mu}{F_{h}}
$$

여기서, $\frac{F_{h}}{A_{c r}}=\frac{F_{h}}{b_{v} l_{v h}}=\frac{M_{\max } /(0.9 d)}{b_{v} l_{v h}}$

Case-III의 접합면 전단강도 상한치를 계산하기 위한 콘크리트의 압축강도는 Table 5 의 시험 결과를 사용하였 으며, 접합면의 거칠기를 반영한 마찰계수를 각각 0.6 과 1.0 으로 적용한 경우 $\mathrm{ACI}$ 및 $\mathrm{PCI}$ 에 의한 접합면 전단강 도를 산정하여 Table 7에 나타내었다.

접합면 전단설계시 Case-II에 해당하는 모든 실험체 (SF-291A, SF-291B, SF-291C)는 Table 7에서 보여지는 바
와 같이 3 가지 방법으로 각각 구한 접합면 전단강도 $\left(\mathrm{V}_{\mathrm{nh}}\right)$ 보다 큰 값의 수평전단력 $\left(\mathrm{F}_{\mathrm{h}}\right)$ 을 나타내고 있다. 이는 $\mathrm{ACI}$ 및 $\mathrm{PCI}$ 의 설계기준으로 산정한 접합면의 수평전단강도는 안전측의 입장에서 실험체의 수평전단내력을 평가하는 것으로 볼 수 있다. 즉 레이턴스 제거여부, 전단키 설치 및 거칠기의 실험변수를 갖는 실험체의 실제강도는 합성 보의 수평전단력 전달메커니즘으로 산정한 전단강도 보 다 1.34 1.58배 큰 값을 보여주었다.

Case-II에 해당하는 실험체에서 실험변수인 접합면의 레이턴스 제거 유무, 전단키 설치 등은 실험체의 수평전 단내력을 크게 변화시키지는 않았지만 접합면 표면에 지 연제를 살포하여 레이턴스를 제거한 SF-291B 실험체가 가장 큰 값의 실험강도를 보여주고 있다. 반면 레이턴스 존치 상태의 SF-291A 실험체나 전단키가 설치되었지만 수평전단력에 의한 직접전단에 의한 파괴로 인한 미끄러 짐 변형이 나타날 수 있는 SF-291C 실험체는 상대적으로 작은 실험강도를 나타내었다. 따라서 접합면의 레이턴스 를 제거하고 표면을 거칠게 처리하는 시공상세 조건은 합성보의 수평전단력 전달메커니즘으로 접합면 전단설계 를 수행할 때 사전 확인이 필요한 중요사항이라고 판단 된다. 한편 Table 7에서 마찰계수 1.0 에 대응하는 유효마 찰계수를 사용하여 전단마찰강도를 산정한 $\mathrm{PCI}$ 의 수평전 단강도 산정 결과는 1.18 1.64의 범위내에서 실험강도를 예측하는 것으로 나타났다. 반면 마찰계수를 1.0 및 0.6 으 로 적용한 $\mathrm{ACI}$ 의 전단마찰설계법과 마찰계수 0.6 에 대응

Table 7 Observed horizontal shear strength for specimens

\begin{tabular}{|c|c|c|c|c|c|c|c|c|c|c|c|c|c|c|c|}
\hline \multirow{4}{*}{ Specimen } & \multirow{2}{*}{\multicolumn{2}{|c|}{$\begin{array}{l}\text { Calculated } \\
\text { strength }\end{array}$}} & \multirow{4}{*}{$\begin{array}{l}P_{\max } \\
(\mathrm{kN})\end{array}$} & \multirow{4}{*}{$\begin{array}{c}\mathrm{M}_{\max } \\
(\mathrm{kN} \cdot \mathrm{m})\end{array}$} & \multicolumn{6}{|c|}{ Horizontal shear at the interface $(\mathrm{kN})$} & \multicolumn{5}{|c|}{ Tested / calculated } \\
\hline & & & & & \multirow{3}{*}{$\begin{array}{r}\text { (1) } \mathrm{F}_{\mathrm{h}} \\
\left(=\frac{M_{\max }}{0.9 d}\right)\end{array}$} & \multirow{3}{*}{$\begin{array}{c}(2) \\
\mathrm{V}_{\mathrm{nh}}{ }^{(1)} \\
(17.5 .3)\end{array}$} & \multicolumn{2}{|c|}{$\mathrm{V}_{\mathrm{nh}}^{(2)}$ (ACI11.7.4) } & \multicolumn{2}{|c|}{$\mathrm{V}_{\mathrm{nh}}{ }^{(3)}$ (PCI4.3.6) } & \multirow{3}{*}{$\frac{(1)}{(2)}$} & \multirow{3}{*}{$\frac{(1)}{(3)}$} & \multirow{3}{*}{$\frac{(1)}{(4)}$} & \multirow{3}{*}{$\frac{(1)}{(5)}$} & \multirow{3}{*}{$\frac{(1)}{(6)}$} \\
\hline & \multirow{2}{*}{$\begin{array}{l}2 \mathrm{~V}_{\mathrm{n}} \\
(\mathrm{kN})\end{array}$} & \multirow{2}{*}{$\begin{array}{c}2 \mathrm{M}_{\mathrm{n}} / \mathrm{a} \\
(\mathrm{kN})\end{array}$} & & & & & (3) & (4) & (5) & (6) & & & & & \\
\hline & & & & & & & $\mu=0.6$ & $\mu=1.0$ & $\mu=0.6$ & $\mu=1.0$ & & & & & \\
\hline SF-1027 & 3435 & 2642 & 1770 & 929.3 & 1986 & 1470 & 1848 & 2310 & $\begin{array}{c}2310 \\
\left(\mu_{e}=0.75\right)\end{array}$ & $\begin{array}{c}2898 \\
\left(\mu_{e}=1.25\right)\end{array}$ & 1.35 & 1.07 & 0.86 & 0.86 & 0.69 \\
\hline SF-685A & 2490 & 2546 & 1912 & 1003.8 & 2145 & 1470 & 1232 & 2054 & $\begin{array}{c}1632 \\
\left(\mu_{e}=0.79\right)\end{array}$ & $\begin{array}{c}2719 \\
\left(\mu_{e}=1.32\right)\end{array}$ & 1.46 & 1.74 & 1.04 & 1.31 & 0.79 \\
\hline SF-685B & 2490 & 2546 & 1719 & 902.5 & 1928 & 1470 & 1232 & 2054 & $\begin{array}{c}1815 \\
\left(\mu_{e}=0.88\right)\end{array}$ & $\begin{array}{c}2898 \\
\left(\mu_{e}=1.41\right)\end{array}$ & 1.31 & 1.56 & 0.94 & 1.06 & 0.67 \\
\hline SF-291A & 1793 & 1757 & 1744 & 915.6 & 1884 & 1280 & 524 & 874 & $\begin{array}{c}790 \\
\left(\mu_{e}=0.90\right)\end{array}$ & $\begin{array}{c}1317 \\
\left(\mu_{e}=1.51\right)\end{array}$ & 1.47 & 3.59 & 2.16 & 2.38 & 1.43 \\
\hline SF-291B & 1784 & 1747 & 1867 & 980.2 & 2017 & 1280 & 524 & 874 & $\begin{array}{c}738 \\
\left(\mu_{e}=0.84\right)\end{array}$ & $\begin{array}{c}1230 \\
\left(\mu_{e}=1.41\right)\end{array}$ & 1.58 & 3.85 & 2.31 & 2.73 & 1.64 \\
\hline SF-291C & 1812 & 1773 & 1584 & 831.6 & 1711 & 1280 & 524 & 874 & $\begin{array}{c}870 \\
\left(\mu_{e}=1.00\right)\end{array}$ & $\begin{array}{c}1450 \\
\left(\mu_{e}=1.66\right)\end{array}$ & 1.34 & 3.26 & 1.96 & 1.97 & 1.18 \\
\hline
\end{tabular}

where, (1) $V_{n h}=\left(1.8+0.6 \rho_{v} f_{y}\right) \lambda b_{v} l_{v h} \leq 3.5 b_{v} l_{v h}$

(2) $V_{n h}=\mu A_{v} f_{y}$

(3) $V_{n h}=\mu_{e} A_{v} f_{y}$ 
하는 유효마찰계수를 사용한 $\mathrm{PCI}$ 의 전단마찰설계법은 실 험체의 수평전단강도 보다 $1 / 2 \sim 1 / 3$ 정도 작은 값의 수평 전단강도 값을 보여주고 있는데, 이는 과도하게 안전측 의 설계 결과를 제공하는 것으로 판단된다.

Case-III에 해당하는 실험체는 전단마찰설계법으로 접 합면 강도를 산정하기 위하여 계획한 것으로서 SF-1027, $\mathrm{SF}-685 \mathrm{~A}$ 및 $685 \mathrm{~B}$ 실험체의 경우 마찰계수를 0.6 으로 적 용하여 산정한 $\mathrm{ACI}$ 의 전단마찰강도 보다 $1.07 \sim 1.74$ 배 큰 값의 실험강도를 나타내었다. 한편 SF-1027을 제외한 2 개의 실험체는 마찰계수 0.6 에 대응하는 유효마찰계수를 사용한 $\mathrm{PCI}$ 의 전단마찰강도 보다 1.06 1.31배의 범위에 서, 그리고 마찰계수를 1.0 으로 적용한 $\mathrm{ACI}$ 의 전단마찰 강도는 0.94 1.04배의 수준으로 실험강도를 평가할 수 있 었다. 반면 마찰계수 1.0 에 대응하는 유효마찰계수를 사 용한 $\mathrm{PCI}$ 의 전단마찰강도는 실험체의 강도를 과대평가하 고 있으므로 실제 설계과정에서 적용한다면 안전성에 문 제가 발생할 수 있다. 즉 Case-III에 해당하는 실험체 중 에서 SF-1027을 제외한 2개의 실험체는 마찰계수를 1.0 으로 사용할 경우, $\mathrm{ACI}$ 의 전단마찰강도는 실험체의 실제 수평전단파괴 강도와 유사하지만 $\mathrm{PCI}$ 의 전단마찰강도는 비안전측의 평가 결과를 보여주고 있다. 그러나 마찰계 수를 0.6 으로 사용한 경우 $\mathrm{ACI}$ 의 전단마찰강도는 지나치 게 보수적으로 접합면의 전단강도를 평가하고 있지만, $\mathrm{PCI}$ 의 전단마찰강도는 실험체의 수평전단강도와 유사하 게 나타나고 있다. 한편 전단철근의 정착단부에 콘크리 트가 묻는 현상과 전단마찰성능의 관계를 시험하기 위한 SF-685 시리즈의 실험 결과에 의하면 $\mathrm{PC}$ 제작과정에서 전단철근의 정착단을 비닐로 보양한 SF-685A 실험체의 내력이 $11 \%$ 가량 크게 나타났다. 따라서 깨끗한 표면을 갖는 전단철근의 관리는 접합면의 전단성능 확보를 위하 여 필요한 사항이라고 판단된다.

전단마찰설계법으로 접합면의 전단강도를 산정할 경 우 Case-II와 Case-III의 전 구간에서 마찰계수 0.6 에 대응 하는 유효마찰계수를 사용한 $\mathrm{PCI}$ 의 전단마찰설계법은 $\mathrm{ACI}$ 의 경우보다 실험체의 실제 수평전단강도를 정확하게 예 측하는 것으로 나타나고 있다.

SF-1027 실험체의 실험강도는 마찰계수 1.0 에 대한 $\mathrm{ACI}$ 및 $\mathrm{PCI}$ 의 전단마찰강도 보다 $14 \% \quad 31 \%$ 정도 작게 나타나고 있다. 이러한 현상의 원인은 이 연구의 실험변 수만으로는 명확하게 파악할 수 없는 상황이며, 추후 연 구에 의한 규명이 필요한 부분이다. 따라서 합성 $\mathrm{PC}$ 보의 접합면 전단강도 산정을 위한 접합면 전단응력 $\left(\mathrm{v}_{\mathrm{u}}\right)$ 의 최 대값은 향후 충분한 실험 결과에 의해 안전성을 확인하 기 전까지는 $4.8 \mathrm{MPa}(=700 \mathrm{psi})$ 이하로 제한하여 사용하 는 것이 바람직하다.

Fig. 9 에서는 기존연구에서 실험한 57 개의 합성보 실험 체 $^{5-9}$ 에 대한 접합면 전단강도와 이 연구의 접합면 전단 성능 실험체의 전단강도를 설계기준의 전단강도와 비교 하여 보여주고 있다. 설계기준의 전단강도 산정을 위한

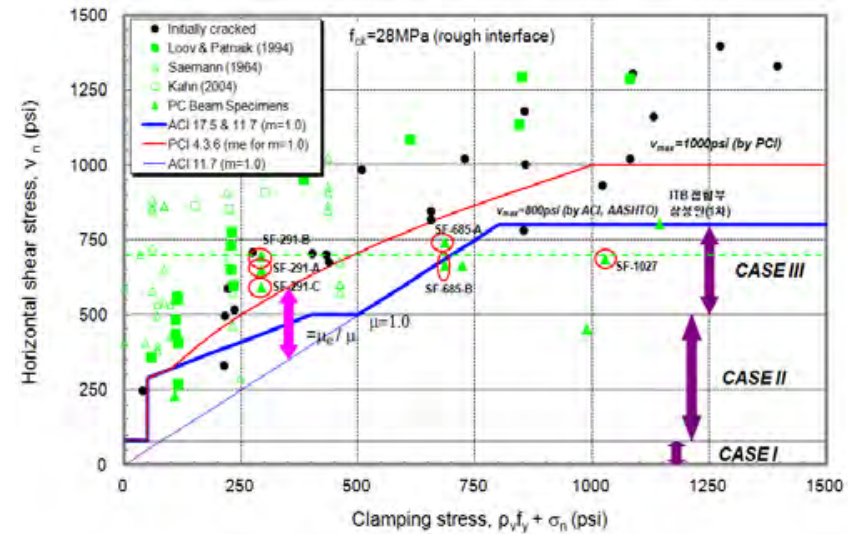

(a) for $\mu=1.0$

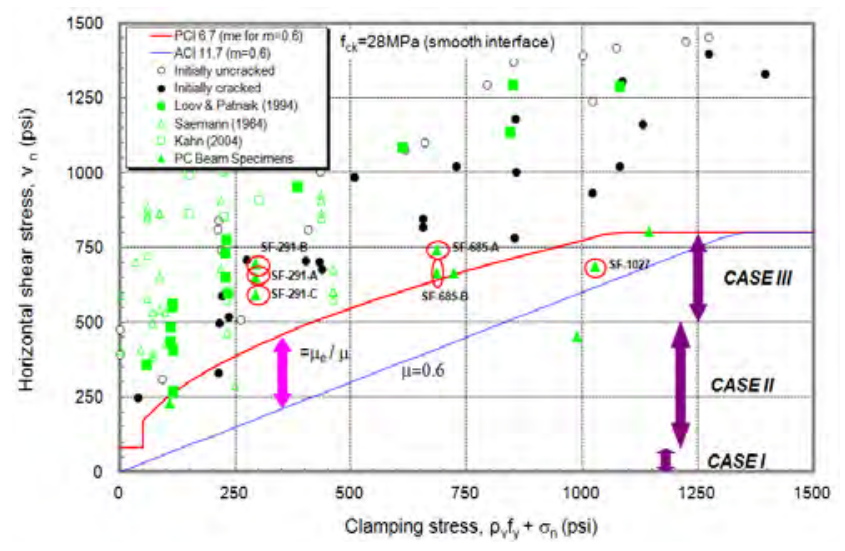

(b) for $\mu=0.6$

Fig. 9 Horizontal shear strength for specimens

마찰계수를 1.0 으로 적용한 Fig. 9(a)에 의하며, 실험체의 접합면 전단강도를 보다 정확하게 평가하기 위해서는 Case-II의 범위에서는 유효마찰계수를 사용한 $\mathrm{PCI}$ 의 전단 마찰설계법이 적당하고, Case-III에서는 마찰계수를 그대 로 사용하는 $\mathrm{ACI}$ 의 전단마찰설계법이 적합한 것으로 판 단된다.

한편 설계기준의 전단강도 산정을 위한 마찰계수를 0.6으로 적용한 Fig. 9(b)는 Case-II와 Case-III의 전 구간 에서 유효마찰계수를 사용한 $\mathrm{PCI}$ 의 전단마찰설계법이 $\mathrm{ACI}$ 의 경우보다 접합면의 전단강도를 적절하게 평가하 는 것으로 나타나고 있다.

그러나 SF-1027 실험체의 경우는 마찰계수를 0.6 또는 1.0 으로 산정한 $\mathrm{ACI}$ 또는 $\mathrm{PCI}$ 의 전단마찰 설계강도 보다 작은 값의 접합면 전단강도를 나타내고 있으며, 부모멘 트가 크게 작용하는 합성 $\mathrm{PC}$ 보의 특성을 감안할 때 접합 면 전단응력 $\left(\mathrm{v}_{\mathrm{u}}\right)$ 의 최대값은 $4.8 \mathrm{MPa}(=700 \mathrm{psi})$ 이하가 되 도록 설계하는 것이 필요다고 사료된다.

\section{6. 합성 PC보의 접합면 전단설계 방안}

접합면 전단성능 실험체는 합성 $\mathrm{PC}$ 공법의 $\mathrm{PC}$ 부재(half보 또는 ITB)와 덧침 콘크리트 사이의 접합면에서 발생 할 수 있는 미끄러짐 파괴특성과 수평전단강도를 평가하 
기 위하여 계획한 것이다. 총 6 개의 접합면 전단성능 실 험체 중에서 휨압축파괴를 나타낸 SF-291B 실험체를 제 외하면, 모든 실험체가 실험계획에서 의도한 대로 접합 면의 수평전단에 의하여 파괴되었다.

실험 결과의 분석에 의하면, 설계기준에서 규정한 합 성보의 수평전단력 전달 또는 전단마찰 설계법으로 산정 한 접합면 전단강도는 실험체의 수평전단 파괴를 초래한 접합면의 수평전단내력을 양호한 수준으로 평가하는 것 으로 나타났다. 따라서 $\mathrm{PC}$ 부재와 덧침 콘크리트 사이의 접합면은 Fig. 3에 나타난 배근상세와 $\mathrm{PCI}$ 의 정착길이를 적용한 전단철근을 보강함으로써 접합면에서 요구되는 수평전단성능을 확보할 수 있다.

이 연구의 결과에 의하면 $\mathrm{PC}$ 부재와 덧침 콘크리트 사 이의 접합면에 대한 수평전단강도를 산정하는 설계법은 두 가지 방법으로 제시할 수 있다. 첫 번째 전단설계법은 Fig. 10(a)와 같이 마찰계수 $(\mu) 1.0$ 을 사용하면서 콘크리 트구조설계기준 혹은 $\mathrm{ACI}$ 기준을 따르는 방법이다.

두 번째 방법은 Fig. 10 (b)와 같이 마찰계수 $(\mu)$ 0.6에 대응하는 유효마찰계수 $\left(\mu_{e}\right)$ 를 산정하여 접합면의 수평전 단강도를 산정하는 PCI 방법을 사용하는 것이다. 그리고 접합면 전단강도의 산정시 접합면 전단응력 $\left(\mathrm{v}_{\mathrm{u}}\right)$ 은 SF-1027 실험체와 같은 내력특성이 나타나지 않도록 최대값을 $4.8 \mathrm{MPa}(=700 \mathrm{psi})$ 로 제한하여 사용할 필요가 있다.

\section{7. 결 론}

이 연구는 합성보의 접합면에 대한 수평전단성능을 평가

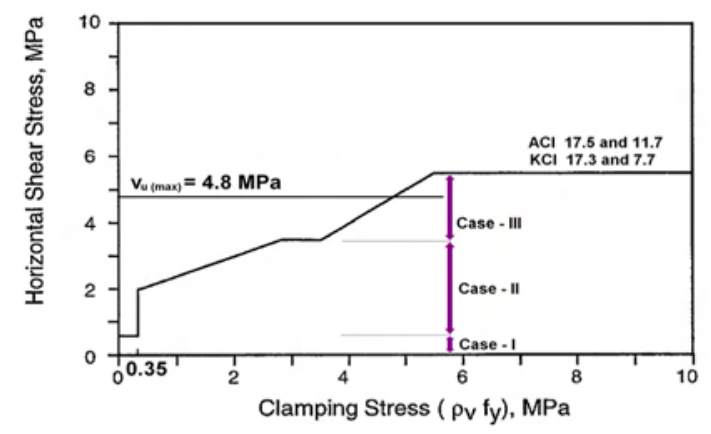

(a) Method 1 for Interface

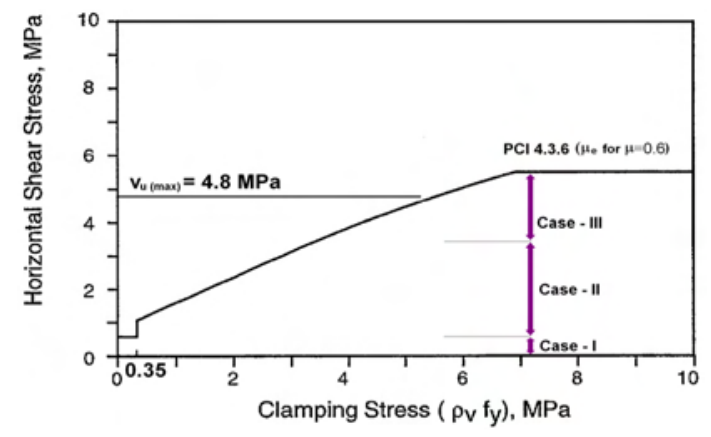

(b) Method 2 for Interface
하기 위하여 접합면의 표면상태, 전단철근의 보강량과 상 세 등의 구조변수를 대상으로 접합면 전단성능 실험체의 수평전단강도를 평가하였다. 주요 연구 결과는 다음과 같다.

1) 휨압축파괴를 나타낸 SF-291B 실험체를 제외하면, 모든 실험체는 실험계획에서 의도한 대로 휨에의해 지배되는 거동특성과 함께 휨모멘트 작용시 요구되 는 인장력이 수평전단력으로 접합면에 작용하면서 접합면의 수평전단 파괴특성을 보여주었다.

2) 접합면의 레이턴스 제거 유무, 전단키 설치 등의 실 험변수를 갖는 Case II의 실제강도는 합성보의 수평 전단력 전달강도 보다 1.34 1.58배 큰 값을 보여주 었으며, 마찰계수 1.0 에 대응하는 유효마찰계수로부 터 전단마찰강도를 산정한 $\mathrm{PCI}$ 의 수평전단강도는 1.18 1.64의 범위에서 실제강도를 예측하는 결과를 나타내었다.

3) 합성보의 수평전단력 전달메커니즘으로 접합면 전 단설계를 수행할 때 접합면 표면에 지연제를 살포 하여 레이턴스를 제거하고 표면을 거칠게 처리하는 시공상세 조건은 설계강도 이상의 수평전단내력을 확보할 수 있는 유효한 수단이라고 판단된다.

4) 전단철근의 보양효과를 평가한 SF-685 시리즈의 실 험결과에 의하면 $\mathrm{PC}$ 제작과정에서 전단철근의 정 착단을 비닐로 보양한 실험체의 내력이 $11 \%$ 크게 나타났다. 이는 깨끗한 표면을 갖는 전단철근의 관 리는 접합면 전단성능 확보를 위하여 필요한 사항 이라고 판단된다.

5) Case III의 SF-685A 및 SF-685B1027을 제외한 2개 의 실험체는 마찰계수 0.6 에 대응하는 유효마찰계 수를 사용한 $\mathrm{PCI}$ 의 전단마찰강도 보다 1.06 1.31배 의 범위에서, 그리고 마찰계수를 1.0 으로 적용한 $\mathrm{ACI}$ 의 전단마찰강도는 $0.94 \sim 1.04$ 배의 수준으로 실 험강도를 평가할 수 있었다.

6) 전단마찰설계법으로 접합면의 전단강도를 산정할 경우 Case-II와 Case-III의 전 구간에서 마찰계수 0.6 에 대응하는 유효마찰계수를 사용한 $\mathrm{PCI}$ 의 전단마 찰설계법은 $\mathrm{ACI}$ 의 경우보다 실험체의 실제 수평전 단강도를 정확하게 예측하고 있다.

7) $\mathrm{PC}$ 합성보의 접합면 전단설계는 마찰계수 $(\mu) 1.0$ 을 사용하면서 콘크리트구조설계기준 혹은 $\mathrm{ACI}$ 기준 을 따르는 방법, 또는 마찰계수 $(\mu) 0.6$ 에 대응하는 유효마찰계수 $\left(\mu_{e}\right)$ 로 부터 전단마찰강도를 산정하는 PCI 방법을 적용하는 것이 바람직하다고 판단되었다.

8) SF-1027 실험체의 실험강도는 마찰계수 1.0 에 대한 $\mathrm{ACI}$ 및 $\mathrm{PCI}$ 의 전단마찰강도 보다 $14 \% ~ 31 \%$ 정도 작게 나타나고 있다. 따라서 합성 $\mathrm{PC}$ 보의 접합면 전단강도 산정을 위한 접합면 전단응력 $\left(\mathrm{v}_{\mathrm{u}}\right)$ 의 최대 값은 향후 실험 결과에 의해 안전성을 확인할 때까 지 $4.8 \mathrm{MPa}(=700 \mathrm{psi})$ 이하로 제한하여 사용할 필요 가 있다.

Fig. 10 Shear design 


\section{감사의 글}

이 논문은 2012년도 한남대학교 학술연구조성비 지원 에 의하여 연구되었으며, 이에 감사드립니다.

\section{참고문헌}

1. Korea Concrete Institute, Concrete Design Code and Commentary, Kimoondang Publishing Company, Seoul, Korea, 2003, 405 pp.

2. ACI Committee 318, Building Code Requirements for Structural Concrete and Commentary (ACI 318M-05), American Concrete Institute, MI, USA, 2005, 436 pp.

3. PCI Industry Handbook Committee, PCI Design HandbookPrecast Prestressed Concrete, 6th Edition, Precast/Prestressed Concrete Institute, Chicago, IL, USA, 2005, 736 pp.

4. PCA, Notes on Building Code Requirements for Structural
Concrete, IL, USA, 2005, 1008 pp.

5. Mattock, A. H., "Anchorage of Stirrups in a Thin Castin-Place Topping," PCI Journal, Vol. 32, No. 6, 1987, pp. $70-85$.

6. Kahn, L. F. and Slapkus A., "Interface Shear in High Strength Composite T-Beams," PCI Journal, Vol. 49, No. 4, 2004, pp. 102-110.

7. Loov, R. E. and Patnaik, A. K., "Horizontal Shear Strength of Composite Concrete Beams with a Rough Interface," PCI Journal, Vol. 39, No. 1, 1994, pp. 48-69.

8. Saemann, J. C. and Washa, G. W., "Horizontal Shear Connections between Precast Beams and Cast-in-Place Slabs," Journal of ACI, Vol. 61, No. 11, 1964, pp. 1383-1409.

9. Shaikh, A. F., "Proposed Revisions to Shear-Friction Provisions," PCI Journal, Vol. 23, No. 2, 1978, pp. 12-21.

요 약 이 연구에서는 합성보의 수평 접합면에 대한 수평전단력 저항성능을 평가하기 위하여 6개의 접합면 전단성능 실험체 를 대상으로 접합면의 표면상태, 전단철근의 보강량과 상세 등의 구조변수에 대한 수평전단강도를 평가하였다. 휨압축파괴를 나 타낸 SF-291B를 제외한 모든 실험체는 실험계획에서 의도한 대로 접합면의 수평전단력에 의한 전단파괴를 나타내었다. 설계기 준식의 수평전단력 전달 또는 전단마찰 설계법으로 산정한 접합면 전단강도는 실험체의 수평전단 파괴를 초래한 접합면의 수평 전단내력을 양호한 수준으로 평가하는 것으로 나타났으며, PCI 설계기준에서 제시한 전단철근의 배근상세와 정착길이는 접합면 에서 요구되는 수평전단성능을 확보할 수 있다고 판단된다.

핵심용어 : 합성 $\mathrm{PC}$ 보, 접합면, 수평전단력, 전단력전달, 전단마찰 